\title{
TV/Series
}

$4 \mid 2013$

Écho et reprise dans les séries télévisées (II) : Re-

présentations -- enjeux socio-culturels, politiques et idéologiques de la reprise

\section{Reflecting the Changing Face of American Society: How 1970's Sitcoms and Spin-Offs Helped Redefine American Identity}

Dennis Tredy

(2) OpenEdition

Journals

Electronic version

URL: http://journals.openedition.org/tvseries/735

DOI: 10.4000/tvseries.735

ISSN: 2266-0909

Publisher

GRIC - Groupe de recherche Identités et Cultures

\section{Electronic reference}

Dennis Tredy, «Reflecting the Changing Face of American Society: How 1970's Sitcoms and Spin-Offs Helped Redefine American Identity », TV/Series [Online], 4 | 2013, Online since 15 December 2013, connection on 01 May 2019. URL : http://journals.openedition.org/tvseries/735 ; DOI : 10.4000/ tvseries.735

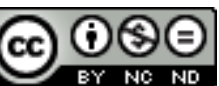

$T V /$ Series est mis à disposition selon les termes de la licence Creative Commons Attribution - Pas d'Utilisation Commerciale - Pas de Modification 4.0 International. 


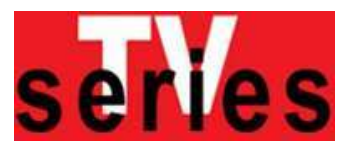

\title{
Reflecting the Changing Face of American Society: How 1970's Sitcoms and Spin-Offs Helped Redefine American Identity
}

\author{
Dennis TREDY
}

\begin{abstract}
When looking back at the popular American situation comedies of the 1970's, one notices a vast network of programs aimed at framing social discourse and at helping America come to term with its own, changing image. This was done through a restaging of the political and social ills of the generation as comedic teleplays, thereby using laughter as a vehicle towards social awareness and unwitting change or personal growth, and by recycling popular (and unpopular) clichés and stereotypes (the bigot, the racist, the bleeding-heart liberal, the closed-minded conservative, the touchy feminist, etc.) so as to undermine them while appearing to reinforce them. As this paper will demonstrate, situations used in these situation comedies were often adaptations of lesser known British television programs (as is the case with Norman Lear's long-running series All in the Family and Sanford and Son), or of landmark films and plays pointing to new social norms (as with Robert Gutchell's Alice or James Komack's The Courtship of Eddie's Father). One also notes that these recycled and reworked premises were in turn recycled and reworked into numerous spinoffs, and even spin-offs of spin-offs, thereby weaving a thick network of popular television programming that attempted to depict every facet and variation of the changing face of American society and to help Americans accept that new face while unabashedly laughing at it. Thus, these television comedies reflected, framed and fed social discourse in the 1970's. Racism, 'reverse racism', religious bigotry, anti-Semitism, draft-dodging, antigovernment protest, women's rights, divorce, and even rape - no topic was too controversial to be treated in the most direct and often vehement of manners in this hardhitting new breed of sitcom. One could argue that American sitcoms have never been as politically incorrect or socially aware as they were some forty years ago, yet it is also undeniable that current programming owes a great deal to these ground-breaking sitcoms of the 1970's. Thus, as a closing point, it is important to note how these programs have served as a palimpsest and a common set of references for today's TV series, and to show how much contemporary 'breakthrough television' owes to the Archie Bunkers, Fred Sanfords and Mary Tyler Moores of the 1970's.
\end{abstract}

$\mathrm{I}$ $f$ the 1960's in the U.S. are generally considered a time of revolution, of civil rights activism and new feminism, of race riots and student riots and riotous clashes between the generations, the television landscape at the time amazingly reflected almost none of that unrest and social strife. 1960's television programming, particularly in terms of sitcoms, was dominated by two genres that seemed to in no way reflect what was often going on right outside the viewers' living rooms: the rural sitcom and the supernatural sitcom, both of which could be seen as a means of soothing escapism. The top-ranking 'rural' sitcoms, all on CBS, included The Andy Griffith Show (1960-68), its spin-off Gomer Pyle USMC (1964-70), The Beverly Hillbillies (196271), Green Acres (1965-71), Petticoat Junction (1963-70) and Hee-Haw (1969-71). Viewers felt lullingly reassured by the grassroots wisdom and old-fashioned horse-sense of heroes like Andy Griffith or of the shenanigans of country bumpkins striking it rich and/or of rich socialites moving out to the sticks. The other dominant sub-genre, on 
all three major networks, was the supernatural sitcom, many of which were also set in rural landscapes. These included $M r$. Ed (the talking horse: CBS, 1961-65), My Mother the Car (a talking automobile: NBC, 1964-66), as well as Bewitched (ABC, 1963-72), I Dream of Jeannie (NBC, 1964-70), My Favorite Martian (CBS, 1963-66), The Ghost and Mrs. Muir (NBC, 1967-70), The Munsters (CBS, 1964-66) and The Addams Family (ABC, 1964-66) - which collectively told the stories of how witches, genies, aliens, ghosts, grandfatherly vampires, cuddly werewolves and other assorted monsters and side-show freaks all somehow coped with living a 'normal' life in the small towns and quiet suburbs of America.

Today we may see these far-fetched fables as a metaphor for the more grueling fight for racial and gender equality, integration and acceptance that was being fought on America's streets, but if so it was about as indirect a connection to divisive civil rights and feminist issues as one could imagine. It was instead a merely suggestive approach on a par with the call for inclusiveness made during the same decade by the original Star Trek series (NBC, 1966-69), which presented a future inter-galactic utopia of tolerance and integration for beings of all species and colors and faiths, a 'United Federation of Planets' - an environment in which Captain James T. Kirk could have color-blind romantic conquests with female aliens of striking Technicolor skin-tones - all of which served to implicitly call for a new philosophy of acceptance of diversity back on earth. However, such indirect and far-fetched calls for inclusion and tolerance would do little to change mentalities or to adequately address the pressing social issues and civil strife of the time.

By the end of the 1960's, that brutal strife and unrest had begun pouring into America's living rooms through breaking news reports on events such as the assassinations of Martin Luther King, Jr. and Robert Kennedy, or the Watt race riots and the Kent State student massacre. It seemed that American sitcom audiences could no longer remain disconnected from these hard truths, and as a means of channeling this uninvited houseguest's presence on the air, and in response to numerous complaints by minority action groups and feminist organizations that minorities and women were either unrepresented or too stereotypically represented on American sitcoms, ABC and NBC, in an attempt to somehow dethrone their dominant CBS rival in ratings, made a first, if somewhat failed, attempt to bring the changing face of America to the small screen.

NBC in particular attempted to turn the tables on the traditional representation of blacks on television by making two popular African American actors - Diahann Carroll and Bill Cosby - each the stars of their own sitcoms, adding Julia and The Bill Cosby Show to the channel's fall line-up in 1968 and 1969, respectively (see Plate 1). 

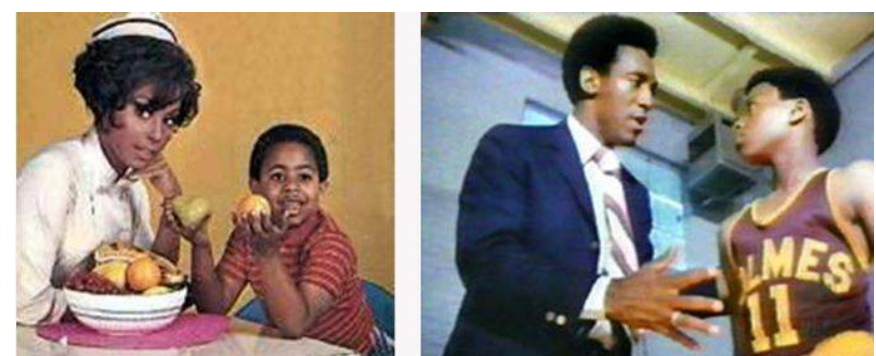

Plate 1: Early 'Ethnicoms' on NBC: Julia (1968-71, 86 ep.) and The Bill Cosby Show (1969-71, 52 ep.)

In spite of this being heralded in TV magazines with headlines like "Black Is the Color of Your New TV," stressing the fact that for the first time a black actress and a black actor were each given their own show, the programs would never really find an audience and would soon be written off by many critics as "warm, plush, middle-class [...] tokenism 2". Julia (NBC, 1968-71, 86 episodes) was perhaps, in the end, the more ground-breaking of the two new 'ethnicoms'. Julia Baker, a single mother and the widow of a Vietnam helicopter pilot, raises her son Corey in a predominantly white L.A. suburb and is financially independent, as she works as a nurse at a health clinic at Aerospace Industries. Though the theme of racism occasionally cropped up [e.g., in the pilot, one doctor is condescending to her because of her race; in a later episode (01.10) her son is called an unspecified racial slur at school, and the first Christmas special (01.14, audaciously entitled "Im Dreaming of a Black Christmas") focused on a dispute between little Corey and his best friend Earl on whether Santa Claus was black or white], on the whole it was the story of Julia's friendships with white neighbors and co-workers who were all, it seemed, remarkably colorblind. Though the program seemed to be preaching by example (both in terms of how black women could move up the social ladder and of how whites should look past a person's color), the program was criticized by minority activist groups for having all of the black characters, most notably Julia herself, dressing and acting like middleclass whites, without the slightest taint of ethnic or cultural difference (hence the accusation of tokenism)3. In the end, the show perhaps did

\footnotetext{
1 Darrell Y. Hamamoto, Nervous Laughter: Television Situation Comedy and Liberal Democratic Ideology, New York, Praeger Publishers, 1989, p.90.

2 Robert Lewis Shayon, "Changes", Saturday Review 53, April 1970, p. 46.

3 Darrell Y. Hamamoto, Nervous Laughter..., p.91; see also Joseph R. Dominick and Bradley S. Greenberg, "Three Seasons of Blacks on Television," Journal of Advertising Research 10 (1970), p.27.
} 
more for the cause of feminism, with its independent and fulfilled single working mother model, regardless of her color.

Similarly, the short-lived Bill Cosby Show (NBC, 1969-71, 52 episodes) would attempt to focus on blacks living like (or as) whites. Cosby played Chet Kincaid, a caring if irreverent high school gym teacher at a predominantly black L.A. high school. Cosby, along with producers Marvin Miller and Ed Weinberger, sought to leave racial tensions out of the picture and tried to demonstrate that black children and families were no different from their white counterparts - a dominant philosophy in Bill Cosby's lifelong views of the representation of African-Americans on television - but the show would come under the same critical fire as Julia would, as it presented a generally color-blind America that seemed generations away, if ever attainable 4 .

Simultaneously, ABC tried to shake things up with two of its own breakthrough programs, which both did slightly better than Carroll's and Cosby's vehicles in terms of ratings and longevity, but did little to change America's consciousness (see plate 2). Here the two programs focused on the didactic teaching of tolerance rather than a would-be colorless society. Room 222 (ABC, 1969-74, 112 episodes) was set in a supposedly inner-city (but remarkably collegiate-looking) public high school in L.A., tellingly named Walt Whitman High School, thus reinforcing its democratic philosophy of integration among the multi-ethnic staff and student body. It centered on white liberal reformer Alice Johnson (Karen Valentine), a student-teacher who occasionally sparred with her more conservative and cynical foil, Principal Seymour Kaufman (Michael Constantine). The other two teachers making up the main cast were both African-Americans - Pete Dixon (Lloyd Haynes), who taught history and life-lessons in 'room 222' of the title, and his fiancée, student counselor Liz McIntyre (Denise Nicholas) - but here again these smartly-dressed, middleclass professionals seemed devoid of any ethnic or cultural difference besides their skin color. It was instead among the students - a crosssection of nearly every possible minority group, symbolically seen happily walking to class together during the opening theme - that occasional inter-cultural tensions sprang up and were quickly smoothed over by one of the watchful and caring teachers. To the show's merit, students did proudly affirm their specific ethnic differences (one black student, for example, sported a dashiki and an afro), and the program often touched on very sensitive issues, such as

4 Note that Bill Cosby's signature color-blind approach would hit the mark much later, for after spending most of the 1970's biding his time with his Saturday morning animated series on life in the ghetto, Fat Albert and the Cosby Kids (CBS, 1972-85), he would return with the most successful sitcom of the twentieth century, The Cosby Show (NBC, 1984-92), the premise of which was precisely that of an African-American family believably and endearingly living the upper-middle-class lifestyle traditionally associated with whites. 
interracial dating, teenage pregnancy, homosexuality and school violence [for example, in one episode (04.17), a student with a history of delinquency brings a gun to school and threatens Alice with physical violence]. However, such issues were calmly resolved by the end of an episode, and, in terms of racial equality, the overriding message of nearly all episodes seemed to be that through hard work and tolerance any minority could integrate white middle-class norms and have access to the American dream.

In another program, The Courtship of Eddie's Father (ABC, 1969-72, 73 episodes), teaching basic lessons in tolerance was the mainstay of the opening and closing discussions between the widower Tom Corbett (Bill Bixby) and his young son Eddie (Brandon Cruz), usually in the form of a difficult-to-answer question posed from a child's perspective, one that his father does his best to answer. The cast was completed by Tom's Japanese housekeeper, Mrs. Livingstone (Miyoshi Umeki), whose broken English and the form of address she used when speaking of Tom ("Mr. Eddie's Father") are alluded to in the show's title. Mrs. Livingstone was a docile but nurturing presence whose wisdom was far beyond her vocabulary, and it was indeed a new and a positive, if somewhat stereotypical, representation of Asian Americans on U.S. television. However, racial, cultural and social tensions were given a very light and kid-friendly treatment on the program, and opportunities to break barriers were often sidestepped. For example, in an episode in which Tom makes a lunch date with a woman he has only spoken to on the phone, the mother of one of Eddie's classmates, he is flabbergasted to discover that she is black when she rings at the door (01.07 - entitled "Guess Who's Coming to Lunch"). The luncheon goes well, with overtones of camaraderie rather than romance, and then the woman simply goes home. In the typical style of the program's ending sequence, Eddie asks his father what would happen if a "grasshopper" married a "bird", to which Tom responds, "You'd get a very jumpy bird!" - thereby implying that the races best be kept separate.

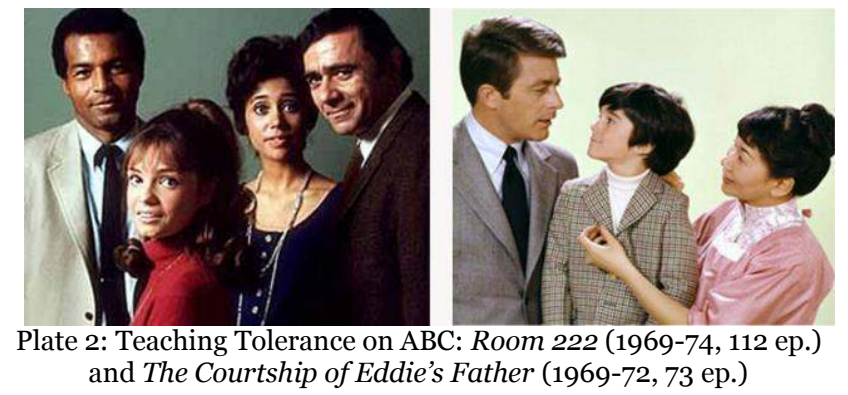


If these four programs, in spite of their merits, missed the mark - in terms of timing, method and viewership - the second wave of attempts to make sitcoms a vehicle for social awareness and social change would begin in the 1970-1971 television season and would forever reshape the landscape of American television. The two main creative forces behind this change were undoubtedly producer-writer Norman Lear and producer-actress Mary Tyler Moore (whom we could refer to, for convenience, as 'King Lear' and 'Queen Mary'), for Lear would produce over twenty often hard-hitting shows and spin-offs that created a new genre and oxymoron, that of "serious comedy", a platform in which the most biting and uncomfortable social issues of the day were put center-stage, and Moore would forever change the image of women on television, through her own series and the many spin-offs it generated.

In many ways, it could be said that the unsung heroes of the change to America that Lear and Moore would bring about were two executives at CBS: Paul Klein, the director of research, and Fred Silverman, the head of programming. Klein's research called into question CBS's ratings advantage through its trademark rural sitcoms by focusing on advertising and demographics. He argued that NBC's vehicles for Diahann Carroll and Bill Cosby appealed to younger and more urban audiences, allowing NBC to charge more for advertising than CBS in spite of lower ratings. When Silverman became head of programming in 1970, he heeded Klein's warning for a change in demographics and, with the unexpected approval of CBS president Robert Wood, enacted what would be known as "the rural purge of 1971 "5. In this astoundingly bold move, CBS suddenly cancelled or wound down nearly all of its most popular sitcoms (from The Andy Griffith Show's sequel Mayberry R.F.D. (1968-71) to The Beverly Hillbillies to Green Acres) and comedy hours (those of Glen Campbell, Jackie Gleason, Ed Sullivan, etc.) - all among the top 30 shows on television - in order to bring in a new generation of more urban and younger audiences. The times they were indeed a-changin', and it was a jaw-dropping gamble that paid off ten-fold and assured CBS's continued supremacy over its two rivals throughout the 1970's.

\section{Queen Mary}

The first new project that Silverman picked up for CBS was The Mary Tyler Moore Show, produced by Moore and her then-husband Grant Tinker's MTM productions, with their trademark meowingkitten bumper in parody of the roaring MGM lion. The show premiered

5 Gary R. Edgerton, The Columbia History of American Television, New York, Columbia University Press, 2007, p. 274-75. 
in September of 1970, lasted for seven years and 168 episodes, won 29 Emmy Awards [a record only broken in 2002 by NBC's Frasier (19932004)], had three spin-offs and revolutionized the image of women in American sitcoms (see plate 3).

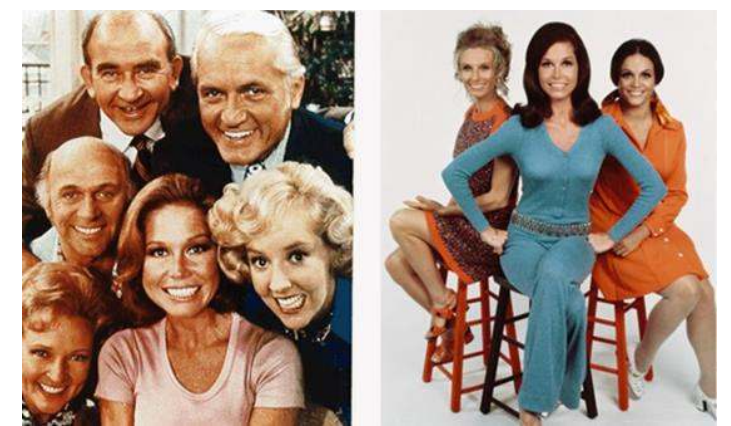

Plate 3: Early Feminist Sitcoms on CBS:

The Mary Tyler Moore Show (1970-77, 168 ep.) and Mary with the stars of two of her show's spin-offs, Rhoda (1973-78, 109 ep.) and Phyllis (1975-77, 48 ep.)

In the pilot, the main character, Mary Richards, leaves her irresponsible fiancé, moves to the big city (in this case, Minneapolis), gets her own apartment, finds a job as an assistant producer on a television news program, and is determined to "make it" on her own (that is, without a man's help) - as the trademark ending of the opening theme reminded us every week, punctuated by Mary's enthusiastic single-and-loving-it hat-toss during rush hour. Moore thereby created the first sitcom about an independent and selfsufficient working woman who had no interest in settling down and forming the nuclear family heretofore idealized on television. One must remember that at this time the only women who were permitted such independence on U.S. sitcoms were widows (like Julia Baker in her earlier show on NBC) - as their sorry, manless plight was through no fault or choice of their own. A divorced female lead was yet to step foot on the stage of a sitcom, and Mary Richards seemed to go one step beyond, by consciously choosing not to marry her fiancé when he came crawling back to her with a wedding proposal and by foregoing prescribed marital bliss and motherhood. Instead, she was perfectly content with casual dating and found fulfillment in her work life and in her friends, which provided the double focus of the show. On the one hand, Mary was the most responsible executive in the WJM newsroom, thereby turning the staff-members there into her surrogate family. This included her gruff but soft-hearted boss, Lou Grant (Ed Asner), her sharp-tongued and quick-witted news-writer Murray Slaughter (Gavin MacLeod, long before his Love Boat set sail on ABC in 1977), and the 
buffoonish and dim-witted anchorman Ted Baxter (Ted Knight). This was thus the first female-centered sitcom to focus on a workplace other than a schoolroom ${ }^{6}$, and it helped start a trend for work-place sitcoms in general that would continue to the 1980's, with shows like Barney Miller (ABC, 1975-82), Taxi (ABC, 1978-82; NBC, 1982-83), Archie Bunker's Place (CBS, 1979-83), Murphy Brown (CBS, 1988-98) and of course Cheers (NBC, 1982-93). The other focus of the program was then Mary's social life with her two best friends, her arrogant and domineering landlady, Phyllis Lindstrom (Cloris Leachman), and her spunky and free-spirited best friend, Rhoda Morganstern (Valerie Harper) - each of whom would have their own spin-offs with a similar feminist message: Rhoda from 1974 to 1978 (109 episodes) and Phyllis from 1975 to 1977 (48 episodes). Thus American audiences were treated to the first all-girl 'BFF' ensemble (i.e., 'best friends forever'), one the likes of which they would not again see until the 1990's, with Sex and the City (HBO, 1998-2004).

By the mid-1970's, CBS would take this feminist trend one step further with two sitcoms that would turn traditional views of familybased sitcoms upside down by featuring the stories of struggling, single working mothers (see plate 4). In Alice (CBS, 1976-1985, 202 episodes), very loosely based on Martin Scorcese's 1974 film Alice Doesn't Live Here Anymore, recently widowed Alice Hyatt (Linda Lavin) leaves New Jersey for Phoenix to get a new start and raise her young son Tommy, getting a thankless job waiting tables at Mel's Diner with two other women, the scatter-brained Vera (Beth Howland) and the man-hungry 'Flo' (Polly Holliday). The other program, One Day at a Time (CBS, 1975-1984, 209 episodes), was far more ground-breaking, though, as it was the story of a divorced working mother - yes, 'divorce' was no longer a dirty word! - Ann Romano (Bonnie Franklin), who moves to Indianapolis fresh from a bitter divorce to raise her two teenage daughters (MacKenzie Phillips and Valerie Bertinelli) - a set-up which allowed this program, unlike its predecessors, to openly deal with controversial issues related to modern teens (drug use, promiscuity, teen pregnancy, etc.). In both cases, though, feminism was the main focus, and the one male protagonist in each of the two shows - Alice's boss Mel Sharples (Vic Tayback) and Ann's superintendent Dwayne Schneider (Pat Harrington) - was a sleazy, overbearing male chauvinist who never managed to get the upper-hand on the street-smart single mom. Thus our feminist heroines' strength shone even brighter by comparison.

\footnotetext{
${ }^{6}$ These earlier working-girl sitcoms that focused on school-teachers included the radioshow-turned-sitcom Our Miss Brooks (CBS, 1952-56), starring Eve Arden as an outspoken English teacher, as well as the above-mentioned Room 222, starring Karen Valentine.
} 


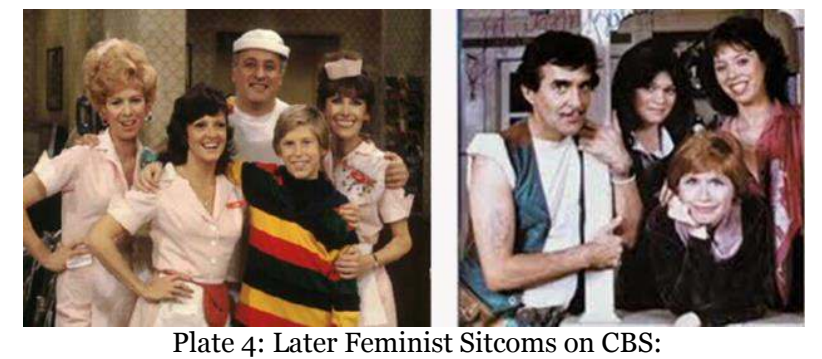

Alice (1976-85, 202 ep.) and One Day at a Time (1975-84, 209 ep.)

\section{King Lear}

However, Mary Tyler Moore's contribution, as important as it was to changing the image of women on television, did little to advance matters of diversity and race, as no minorities were represented on any of the programs. In addition, that the only feminist sitcom listed above that dealt with other controversial social issues of the day was One Day at a Time should come as no surprise when one realizes that it was the only one produced by Norman Lear. Lear's approach to promoting tolerance and liberal causes was indeed far more radical and farreaching, and appears to be at polar opposites with the tactics originally used at NBC and ABC in the late 1960's (those of color-blind ideals and of child-like didactics, as discussed above), when Lear first began reshaping the American sitcom. Lear seemed to understand early on that America's deep-seated problems had to be dealt with head-on if they were ever to be overcome, and that a post-civil-strife society could not be portrayed believably until that same civil strife was given full and uncompromising exposure - to 'lance the abscess', as it were, so that the country could heal.

With this in mind, Norman Lear, the former comedy writer for such viewer-friendly 1950's shows as The Colgate Comedy Hour (NBC, 1950-56) and The Ford Star Jubilee (CBS, 1955-56), and his producerpartner Bud Yorkin, Jr. (through their joint company Tandem Productions), bought the U.S. rights to two very controversial sitcoms in Great Britain in 1968, one of which he would immediately set about adapting for American audiences. The first 'britcom' he revamped was called Till Death Us Do Part (BBC1, 1965-68, 1972-75, 54 episodes), a gritty kitchen-sink style sitcom that staged cut-throat shouting matches within the extremely poor working-class Garnett household in Wapping (see plate 5).

Pitted against the ignorant, reactionary and bigoted rants of loud-mouthed patriarch Alf Garnett (Warren Mitchell) were the equally vocal complaints of his long-suffering, chain-smoking wife (Dandy Nichols) and the socialist/pro-Labour antagonism of his daughter Rita (Una Stubbs) and her unrelenting husband Mike 
(Anthony Booth), Alf's main foil and sparring partner. The show broke many barriers in Britain, notably for using biting comedy to stress social ills and for being the first to allow swear words (like "bloody") or racial slurs (like "coon") in the heated dialogues, but in most cases the given conflict would be resolved by the end of the episode, in true EastEnder fashion, by having Alf and Mike get sloshed together at the local pub or go chummily to a football match 7 .

Norman Lear would rewrite the premise to suit American audiences and issues, creating two pilots for ABC in 1968 and 1969, both of which were turned down and were never aired by the network, who preferred the naively didactic approach mentioned above and funneled resources instead into two very popular sitcoms that gave a very rosy, kitschy (and often musical) portrayal of new family dynamics in the 70's, Sherwood Schwartz's The Brady Bunch (ABC, 1969-74) and Bernard Slade's The Partridge Family (ABC, 1970-74). The first of Lear's unaired adaptations was called "Justice for All", and gave us the basic set-up for what would eventually become the block-buster hit All in the Family. For the unaired 1968 pilot, the Bunkers were in fact called the Justices, and although set in a lower-middle class home in Astoria, Queens, Lear's first adaptation had more in common with its BBC1 model than later versions would. Although Lear had found his Archie and Edith in actors Carroll O'Connor and Jean Stapleton, their on-screen personalities would be somewhat altered before any viewers would see them in the 1970's, for the initial Edith is rather vocal and volatile, and O'Connor clearly seems to be doing an impersonation of Jackie Gleason's beloved loud-mouth Ralph Kramden from The Honeymooners, ${ }^{8}$ right down to the cigar-smoking and similar catch-

\footnotetext{
7 Though Till Death Us Do Part was a comical venue for heated political discussions, matters of racism and diversity were rarely the main focus. For in-depth studies of the representation of minorities and diversity in British sitcoms, see Amandine Ducray's booklength study of the phenomenon [Les Sitcoms ethniques à la télévision britannique de 1972 à nos jours : jusqu'à ce que l'humour nous répare, Paris, Harmattan, 2009], as well as her 2012 article "Take Me Back to Dear Old Blighty? Déplacements, hybridation et oscillation identitaires dans les séries humoristiques à contenu ethnique à la télévision outre-Manche (1972-2011),"TV/Series, vol. 2 (Nov. 2012):

http://www.univ-lehavre.fr/ulh services/Numero-2-Issue-2-novembre-2012.html

8 The Honeymooners was a landmark American sitcom that aired on CBS from 1955 to 1956, based on a popular sketch done by Gleason between 1951 and 1955 on the Dumont Network's Cavalcade of Stars and on CBS's The Jackie Gleason Show. The show was set in a run-down apartment in Brooklyn and revolved around four characters: Ralph Kramden (Jackie Gleason), a hot-headed bus driver whose get-rich-quick schemes never pan out; his long-suffering but quick-witted wife, Alice (Pert Kelton, then Audrey Meadows); his best friend and upstairs neighbor, Ed Norton (Art Carney), a dimwitted sewer worker; and Ed's somewhat prudish wife, Trixie (Joyce Randolph). In only 39 episodes, the program set the standard for working-class family-based sitcoms, has inspired dozens of later television shows and characters [even in animation, as the popular cartoon The Flintstones (ABC, 1960-66) is simply a transposition of the sitcom into pre-historic times], and has become a permanent part of contemporary American culture, notably through the continued popularity of the program through late-night reruns.
} 
phrases (e.g., "You're a pip, you know that?"). The daughter and sonin-law characters (Gloria and Dickie, an Irishman, played by Kelly Jean Peters and Tim McIntyre) are also very belligerent and would need far more than one episode to grow endearing to the public. The pilot also focused on Archie's racism and Dickie's atheism, which most likely prompted the cancellation of the project. However, Lear returned a year later with a second version of the pilot for $\mathrm{ABC}$, this time called "Those Were the Days", a reference to the future show's well-loved theme song, a nostalgic pining for simpler days when "everybody pulled his weight" and "girls were girls and men were men", sung at the piano by Edith and Archie. Lear recast the daughter and son-in-law (now Candice Azzarra and burly Chip Oliver) as less outspoken, as is Edith. Archie dropped the Jackie Gleason impersonation and made the character more of his own, and Lear cut out nearly all of the talk of God and atheism, but ABC still turned it down. However, Fred Silverman at CBS, as part of his plan to revamp his network's themes and demographics, seized the opportunity, had Lear do a third pilot, and gave him a thirteen-episode trial season. All in the Family (CBS, 19701979, 208 episodes) was born (see plate 5).
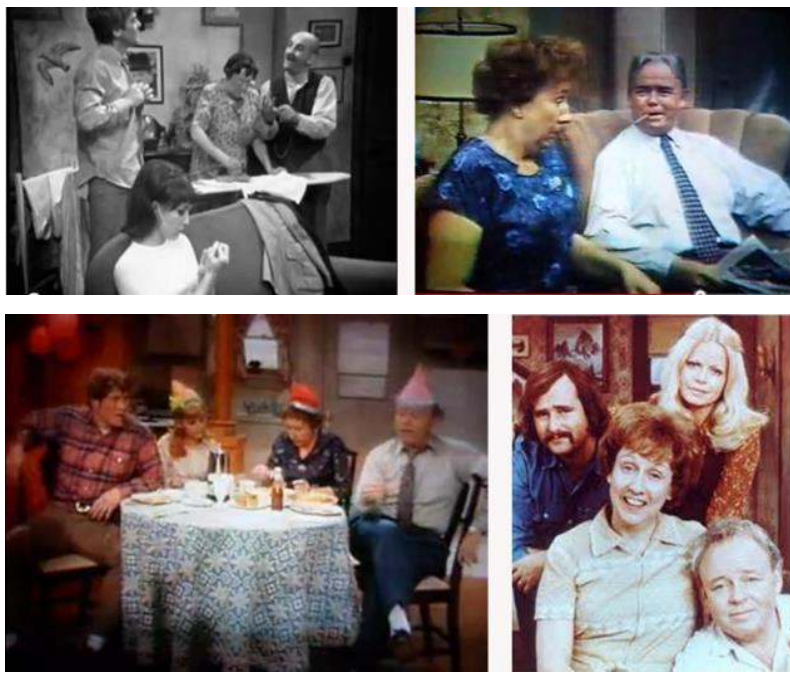

Plate 5: The Development of All in the Family:

From the British sitcom Till Death Us Do Part (BBC1, 1965-68, 1972-75, 54 ep.) to ABC's unaired 1968 pilot Justice for All (top left and right), to a second unaired pilot on ABC in 1969, entitled Those Were the Days (bottom left), to the final version of the series on CBS (bottom right), entitled All in the Family (1970-79, 208 ep.). 
By its network debut, just four months after that of The Mary Tyler Moore Show, all of the kinks had been worked out of the show's characters: O'Connor, a feisty liberal in real life, brought his own composition to Archie Bunker, today the universal archetype for a loud-mouthed, reactionary bigot who inevitably stumbles over his malapropisms and other signs of his own ignorance. Stapleton made Edith the heartwarmingly simple-minded, well-intentioned, longsuffering wife; Rob Reiner took on the role of a more endearing and well-meaning version of the son-in-law, Mike Stivik (a Polish- rather than Irish-American); and Sally Struthers took on what was perhaps the most difficult role of Gloria, as an equally endearing young woman caught between loyalty to her parents and her own liberal beliefs and support of her husband - the three characters being respectively (but disrespectfully) referred to as "dingbat", "meathead" and "little goil" by the antagonistic patriarch. When it first aired, as a decidedly telling midseason replacement for the barnyard antics of Hee-Haw, CBS feared an onslaught of angry calls given the racist language and racy subject matter, hiring teams of extra call-handlers and providing a long disclaimer before each episode of the first season that rather succinctly stated Lear's purpose:

The program you are about to see is All in the Family. It seeks to throw a humorous spotlight on our frailties, prejudices and concerns. By making them a source of laughter, we hope to show, in a mature fashion, just how absurd they are.

These serious lines were followed by the sound of a toilet flushing something that had never been allowed on American television before and that is still referred to today as "the flush heard round the world 9 " - for it heralded a program that would run, including its sequel Archie Bunker's Place (CBS, 1979-83, 97 episodes), for a total of thirteen years and over 300 episodes, that would engender eight spin-offs on CBS and nearly as many lookalikes on other stations, and that would redefine both the American television landscape and the American identity it reflected.

Though there was no flood of calls after the pilot, and initially mediocre ratings, word of mouth and summer reruns would make the program the most popular show on television for five straight years [a record broken only recently by American Idol (Fox, 2002-present)], and it would win 22 Emmy Awards, including Emmys for all four main cast members - another first. The arguing at 704 Hauser Street, Astoria, never died down, and the topics of these disputes also went far beyond Archie's trademark bigotry, as many episodes additionally focused on a specific weekly theme that was also designed to raise eyebrows and raise awareness. These included such controversial

${ }^{9}$ Ken Bloom and Frank Vlastnik, Sitcoms, New York, Black Dog \& Leventhal, 2007, p. 19. 
topics as interracial marriage, homosexuality, feminism, affirmative action, guns and the second amendment, drugs, atheism, draft-dodging and desertion, wife-swapping, menopause, PMS, sexual assault (for Gloria), attempted rape (for Edith), adultery, impotence, alcoholism, and prostitution - and all of this on a sitcom!

From the very first season, it was obvious that Lear had found the right formula, and the impact was immeasurable. Two early episodes seem best to illustrate this. The most talked-about episode of the first season was entitled "Judging Books by Covers" (episode 5, aired February 9, 1971). Mike and Gloria invite over an effeminate male friend of theirs who Archie is convinced is a "pansy", but the tables are turned when Archie learns not only that "Roger the fairy" is straight, but that one of his drinking buddies at Kelsy's Bar, a ruggedly handsome ex-football star, is in fact gay. Reactions to this episode, often violent, could be heard in workplaces and at dinner tables around the country ${ }^{10}$, and, amazingly, even in the Oval Office. Among the Watergate tapes that President Nixon reluctantly turned over to the authorities in 1974 was one dated May 13, 1971 (Watergate tape \#498005), on which President Nixon and his top aides John Elrichman and Bob Haldeman can be heard discussing this episode of All in the Family, which the president happened to come across after watching a football game. In an eye-opening fifteen-minute rant, Nixon sums up the plot of the entire episode for his aides and proceeds to voice his moral outrage, to list the irrevocable dangers of such "glorification of homosexuality", and to explain how the fall of the Roman Empire, of the Catholic Church, of the British Empire and of the glory that was France were all due to such casual acceptance of homosexuality - and how the USA could be next. He even goes on to list all of the known but still-closeted homosexuals on his staff (though a 14-second 'beep' censors the names, a ploy that reminds us of the notorious eighteen and half minutes on the Watergate break-in that were censored-or, rather, "accidentally erased"), and he even praises what he sees as heavy-handed but efficient methods used in Russia and elsewhere to weed out gays without compromise ${ }^{11}$ - declarations that make Archie

\footnotetext{
${ }^{10}$ Aronstein, AJ, "All in the Family and the First Gay Sitcom Character," Splitsider (May 30, 2012): http://splitsider.com/2012/05/all-in-the-family-and-the-first-gay-sitcomcharacter/

11 "Richard Nixon on Civil Rights," 'On the Issues' Website, consulted in May 2012 http://www.ontheissues.org/celeb/Richard_Nixon_Civil_Rights.htm. This site now posts only a short excerpt of the Watergate tape in question. For the full transcript of Nixon's comments on this episode of All in the Family, and for a more detailed analysis of the impact and influence of All in the Family on American culture and identity, see my article “'Those Were the Days...': All in the Family and the 'Primetiming' of U.S. Diversity and Counterculture" in the online review E.O.L.L.E. Vol. II, $n^{\circ} 4$ (Dec. 2012): http://www.univlehavre.fr/ulh services/NUMERO-4.html. The original audio from the Watergate tape \#498-005 can also be consulted at the following Youtube address: http://www.youtube.com/watch?v=TivVcfSBVSM.
} 
Bunker sound quite liberal-minded by comparison! Recent allegations of Nixon's own homosexual affair with his best friend and confidant Charles 'Bebe' Rebonzo are also food for thought on this shocking moment of homophobic rage ${ }^{12}$.

Another famous episode, this time from the second season, was firmly concerned with Archie's prejudice against blacks and Jews and was the most talked-about television program of 1972. Entitled "Sammy's Visit", the episode stages the encounter between Archie Bunker and the celebrity Sammy Davis, Jr. (both black and Jewish), who leaves his briefcase in Archie's cab and later comes to Archie's house to pick it up. Archie is star-struck, and the more he tries to claim a pro-black outlook and prove that he is not prejudiced, the more he puts his foot in his mouth. At the end, as Sammy is leaving, he allows a neighbor to take his picture but insists that Archie pose with him; as the flash goes off, Davis plants a groovy kiss on Archie's aghast cheek, triggering the longest continuous moment of laughter ever recorded by a live studio audience. But the comic overtones allowed for the most direct discussion of racism in America ever broadcast, kissing away even the unheard-of use of the " $n$ - word" during the episode, and thereby perhaps the clearest illustration of Lear's method, as stated in his opening disclaimer.

It was also in 1972 that Lear created his first of many ethnicoms, going far beyond the early attempts made at NBC. He thus adapted the other gritty britcom for which he had bought the U.S. rights in 1968, and was this time given nearly carte blanche by CBS in light of his success with All in the Family. Steptoe and Son (BBC1, 1962-65, 70-74, 54 episodes) was another landmark British sitcom based on social realism and caustic humor, staging the endless disputes between two extremely impoverished 'rag and bone men': the greedy, outspoken, lascivious old man Albert Steptoe (Wilfred Brambell) and his longsuffering ne'er-do-well son, Harold (Harry H. Corbett). Though the main focus was on the generation gap in the 1960's, there was far less social or political banter than there was in Till Death Us Do Part. For Lear's adaptation, Sanford and Son (CBS, 1972-77, 135 episodes), Shepherd's Bush became the Watts ghetto in south-central Los Angeles, and Steptoe Scrap became Sanford Salvage, a junk yard run by overbearing Fred Sanford (Redd Foxx) and his son Lamont (Demond Wilson) (see plate 6).

12 Don Fulsom, Nixon's Darkest Secrets: The Inside Story of America's Most Troubled President, New York, Thomas Dunnee Books, 2012, pp. 48-75. 

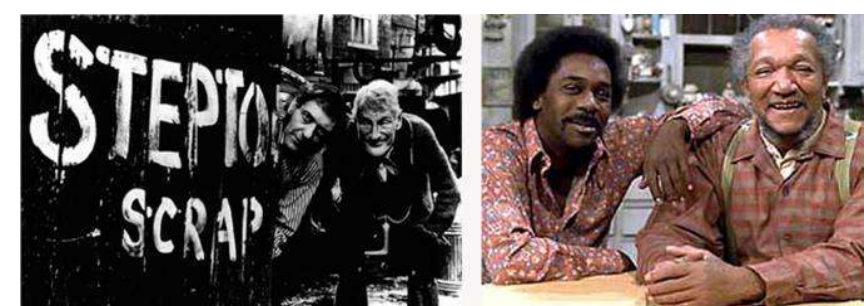

Plate 6: Lear's Second Adaptation of a British Sitcom:

Steptoe and Son (BBC1, 1962-65, 70-74, 54 ep.)

and Lear's Sanford and Son (CBS, 1972-77, $136 \mathrm{ep.)}$

Lear maintained the focus on a very vocal clash of generations, but he injected far more talk of controversial social issues than in its British model, though less than in All in the Family, as most social controversy was limited to the plight of blacks in the ghetto and Sanford's mistrust of whites. Lear basically gave us a dirt-poor, black stand-in for Archie Bunker, and his choice of the notoriously loud- and foul-mouthed comic Redd Foxx for the role (the anti-Bill Cosby at the time) was the key to the show's long-running success.

Similarly, Lear would immediately start to create spin-offs of his now trademark All in the Family so as to further widen the scope of his go-for-the-jugular approach to social issues through comedy (see plate 7). Thus, Edith Bunker's cousin, Maude Findlay (Bea Arthur), from Westchester, New York, was given her own show, Maude (CBS, 197278, 141 episodes). Maude had been Archie's most formidable sparring partner on her visits, as she was a middle-aged, upper-middle-class, out-spoken, quick-witted, domineering über-liberal feminist on her fourth husband, who, especially on her own show, had no qualms about speaking out in favor of abortion, gay rights and civil rights for all minorities. The show was, obviously, nearly as controversial as All in the Family, and nearly as successful, running for six years and 141 episodes, generating its own spin-offs, and making both Bea Arthur and her character Maude Findlay household names.

Even more successful than Maude was the second spin-off of All in the Family, in which one of the Bunkers' neighbors, a loud-mouthed black racist, strikes it rich in the cleaning business and 'moves it on up' from Queens to a "deluxe apartment in the sky" (that is, a penthouse apartment in Manhattan's Upper East Side), as the catchy theme song of The Jeffersons (CBS, 1975-85) reminded us each week. The show would run for an amazing eleven seasons and 253 episodes, staging weekly fights between George (Sherman Hemsley) and his longsuffering but combative wife Weezie (Isabel Sanford), his surly maid Florence (Marla Gibbs), and his socially-conscious son Lionel (Mark Evans), but focusing more on how arrogant, anti-white George had to come to terms with a decidedly white upper-middle-class milieu - and 
how that milieu dealt with a proud and vocal black man in their midst. To spice things up even more, George had to deal with his neighbors and soon-to-be in-laws - an interracial couple named Tom and Helen Willis (the first ever on an American sitcom), whose son was a black man passing for white and whose daughter was soon engaged to George's son Lionel. These clashes were at the heart of every episode, although direct discussion of hot social topics did not have quite the scope and variety of All in the Family.

Not to be completely outdone by CBS, NBC tried to copy the Lear formula, with a slight twist, with Chico and the Man (NBC, 197478), by confronting the conservatism and prejudices of a grouchy old "seventh-generation WASP" named Ed Brown (Jack Albertson) with his sole employee at the garage that he runs in a now black and Hispanic neighborhood in East-Central Los Angeles, the street-smart Mexican-American Chico Rodriguez, played by the extremely popular Hispanic comic, Freddie Prinze. The outspoken and prejudiced Ed Brown had to come to terms with the fact that his neighborhood was no longer white and had become a ghetto/barrio, and that his only friends and neighbors were now either black or Hispanic. The show was a hit and could have had as long a run as Lear's sitcoms, but the star-actor Freddie Prinze's tragic drug-induced suicide put an end to the show after four seasons and 88 episodes.
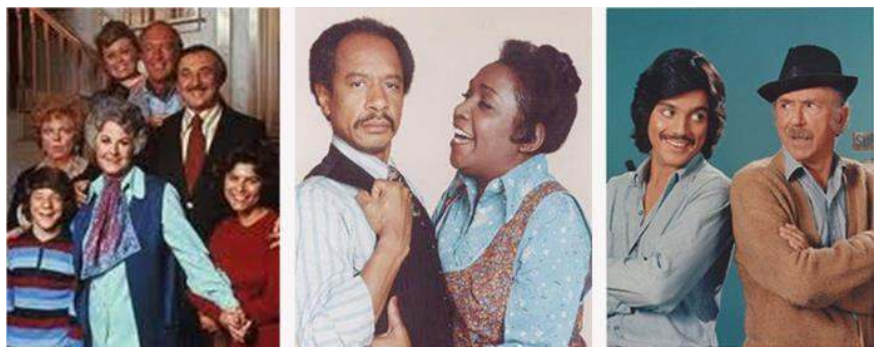

Plate 7: All in the Family Spin-offs and Look-alikes:

Maude (CBS -1972-78, 141 ep.), The Jeffersons (CBS, 1975-85, 253 ep.), and Chico and the Man (NBC, 1974-78, 88 ep.)

Thus, the main ingredient for these successful social-awareness sitcoms by Lear and other producers of what we have called the 'second wave' was the showcasing of loud-mouthed bigots of all creeds (Archie Bunker, George Jefferson, Ed Brown and Fred Sanford) and a few loud-mouthed liberals thrown in for good measure (Maude Findlay and Mike Stivic, for example). Collectively, these shouting matches would echo deep within the American viewer's own psyche, with the bigotry of this team of loud-mouths progressively ringing hollow, outdated and finally ridiculous. Also, as the programs lasted for so many years, viewers witnessed a reluctant but undeniable change occur in such 
characters over time, as each came to accept the new face of American society, in spite of his protests. Thus, Fred Sanford's bigotry fades as the father-and-son bond grows, Ed Brown will come to see Chico as a son and cry a father's tears at his death, George Jefferson will defend even his white friends and in-laws tooth-and-nail, and Archie Bunker will, after Edith's death, open a bar, in which both staff and customers all hail from the minorities against whom he so long was prejudiced and who become his surrogate family.

\section{The New Ethnicom}

The third and final wave of this movement would in many ways be a more timely and successful return to the first, as the racially charged shouting matches of the Lear-dominated second wave had effectively cleared the air, and cleared the path for a more equitable treatment of minorities in the sitcom landscape (see plate 8).

It would again be the Lear-Yorkin team that set this in motion, through a spin-off of Maude (itself a spin-off of All in the Family) called Good Times (CBS, 1973-79, 133 episodes). The two main writers for the program, for the first time, were themselves African-Americans - Eric Monte, who based the show on his own childhood, and Mike Evans, who was the young actor who played George's son Lionel in both All in the Family and The Jeffersons - and it was the story of matriarch Florida Evans (Esther Rolle), Maud Findlay's former maid, who did her best to keep her family together in a mock-up of the destitute Cabrini-Greene housing projects in Chicago. The family included her gambling-addicted and chronically unemployed husband James (John Amos), her promiscuous and saucy daughter Thelma (Bern Nadette Stanis), her goofy starving-artist elder son J.J. (Jimmy Walker), and her younger, socially conscious son Mike (Ralph Carter). The series was a successful attempt to make a traditionally structured sitcom with an all-black family for a black and white audience, and to use the familiar format to enhance awareness of the plight of poor blacks in America and of noted differences in African-American culture and language. Early seasons often dealt with very controversial subjects, typical of the Lear label (e.g. gang violence, racial profiling, alcoholism and drug abuse), but the most vocal complaints about society's unfair treatment of minorities came from the character of young Michael Evans, a budding militant (who, as a mouthpiece for controversial topics, was even named after the show's main writer). Audiences thus accompanied young Michael as he fought much like teenagers of any color, against newly discovered unfairness in the world. As the series wore on, however, the treatment of controversial topics faded as the buffoonish antics of the elder brother J.J. and his trademark catchphrase ("Dyn-o-mite!") stole the show, to such a point that the two adult leads, who were furious about the dumbing-down of 
the show, were eventually killed off (in the case of James) or left the show (in the case of Florida).

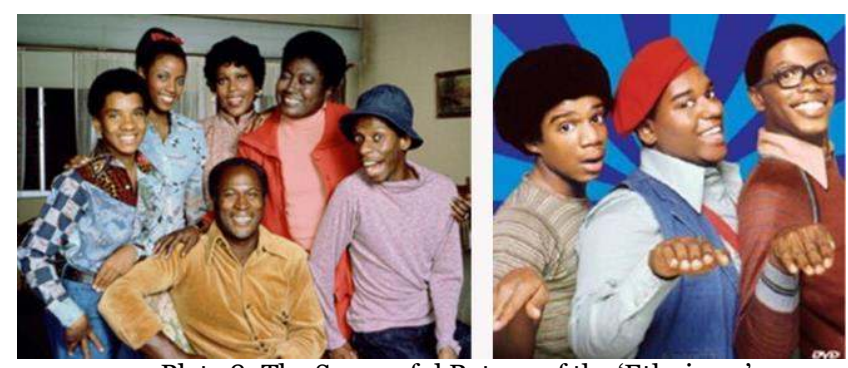

Plate 8: The Successful Return of the 'Ethnicom':

Good Times (CBS, 1973-79, 133 ep.) and What's Happening! (ABC, 1976-79, 65 ep.)

As the trend for accepted pluralism continued, the need for controversial debate on sitcoms indeed seemed to subside, as can be seen by black writer Eric Monte and producer Bud Yorkin's next project, What's Happening! (ABC, 1976-79, 65 episodes). Completely stripped of any controversial topics, the show instead focused on the ups and down of three African-American high school students (Dwayne, Rerun and Raj) in a rather gentrified version of Watts, Los Angeles - and, in spite of the all-black cast, the plot lines were not race-specific and tended to demonstrate that black and white adolescents were essentially the same. It seems that the Bill-Cosby approach, which had failed so miserably six years earlier, had finally come of age.

Similarly, by the mid- to late-1970's, the 'happy diversity' approach that had not made much headway with Room 222 was now readily accepted by the viewing audience (see plate 9). The renewed trend first targeted more adult audiences with the long-running sitcom Barney Miller (ABC, 1975-82, 170 episodes) and the camaraderie that reigned among the multi-ethnic team of detectives at a Manhattan police station. In every episode, an Asian, a Polack, a Negro, a Jew, an Italian, an Irishman and a Puerto-Rican walked into the precinct room - and although that may sound like the opening line to some racist joke, it was not. All were on equal footing, all were equally quirky and funny, and racial tension never reared its angry head.

For younger audiences, there was Welcome Back, Kotter! (ABC, 1975-79, 95 episodes) and the long-running sister-shows Diffrent Strokes (NBC and then ABC, 1978-1986, 189 episodes) and The Facts of Life (NBC, 1979-87, 201 episodes) (see plate 9). In the first, Gabe Kotter (played by comedian Gabe Kaplan) returns to Brooklyn to teach history and life-lessons to problem students (known as the "sweat- 
hogs") at a local high school, a zany group of underachievers that included an African-American (Freddy 'Boom-Boom' Washington), a Puerto-Rican (Juan Epstein), a Jew (Arnold Horshack) and a slowwitted Italian-American (Vinnie Barbarino - the role that launched the career of John Travolta). Similarly, in The Facts of Life, Edna Garret (Charlotte Rae) teaches comparable life-lessons to her young wards at the all-female Eastland Boarding School in Peekskill, New York. Though there is a mix of races and ethnicities among the girls, the cross-section is more one of wealth and class, from the snobbish rich-kid Blair Warner down to the street-wise bad-girl 'Jo' Polniaczek. In both cases, a more simplistic and didactic approach to teaching tolerance, fairness and acceptance was the driving force of the program, both using a school setting as a backdrop for life lessons (as Room 222 had attempted to do so many years earlier). Controversial topics, when they did crop up, were more in line with universal teenage problems. Diffrent Strokes, the theme song of which was itself a catchy ode to pluralism and tolerance, just as the spelling of the title was an attempt to emulate African-American dialect, is perhaps the most obvious example of how previously failed methods of "happy diversity" and kid-friendly (though often naïve) didacticism had finally found their moment and their audience. The premise of the program is wellknown to all - rich white widower Philip Drummond (Conrad Baine, formerly of Maude) adopts and raises two young Harlem-bred, African-American orphans (Arnold, played by Gary Coleman, and Willis, played by Todd Bridges), along with his own (white) teenage daughter Kimberly (Dana Plato), in a deluxe Park Avenue penthouse apartment maintained by a series of motherly house-keepers (the first of which was Charlotte Rae, before her character Edna Garret left for her own show, The Facts of Life, early in the second season). Though the premise seemed ground-breaking - that of "one big happy family" composed of people of different races, different upbringing, and different social classes - the show rarely dealt with profound social issues and instead sought to focus on providing a more simplistic example of "happy diversity" for American viewers, it was hoped, to emulate. These shows all ran well into the 1980's, when the more antagonistic Lear method of what we have called the 'second wave' had all but disappeared. 

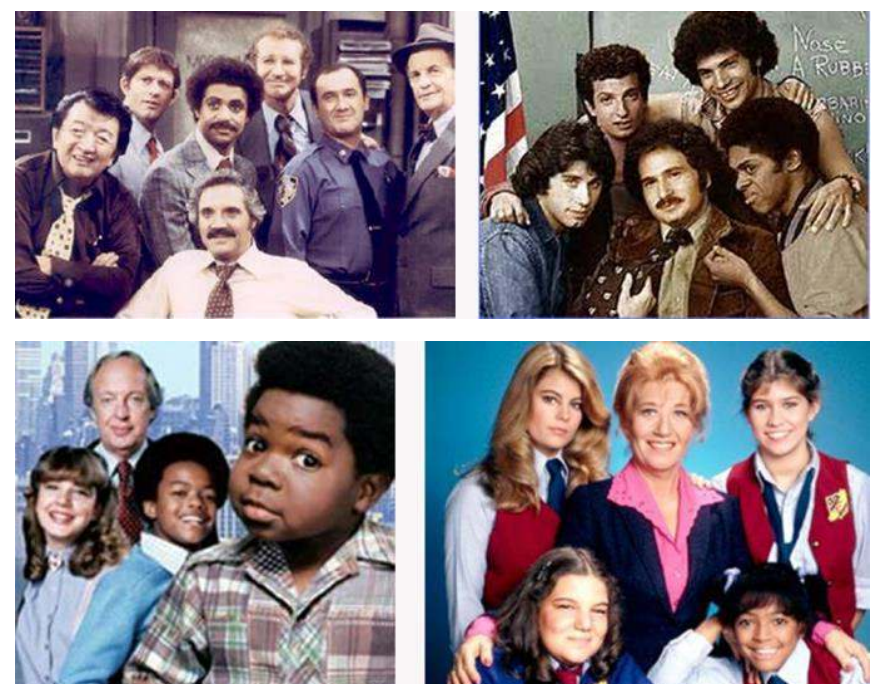

Plate 9: 'Happy Diversity' and Teaching Tolerance:

Barney Miller (ABC, 1975-82, 170 ep.), Welcome Back, Kotter! (ABC, 1975-79, 95 ep.), Diffrent Strokes (NBC/ABC, 1978-86, 189 ep.), and The Facts of Life (NBC, 1979-87, $201 \mathrm{ep.})$

Thus, though Norman Lear's Tandem Productions had a hand in producing Diffrent Strokes and The Facts of Life, by the early 1980's it seemed that America had moved past its need for his trademark display of full-frontal conflicts and self-diffusing bigotry. The 1970's will thus forever be remembered as the reign of King Lear, and although he would return with other radical sitcom ideas in later years - such as the interactive sitcom The Baxters (syndicated, 1979-81), in which the sitcom portion lasted only fifteen minutes, after which the cameras turned on the studio audience for an open debate on the controversial topic of the day, or 704 Hauser (CBS, 1994-95), in which a married couple, both aging black liberals, move into Archie Bunker's old house and have heated arguments with their son, a black conservative, and his fiancée, a white, conservative Jew, thereby giving us a $180^{\circ}$ spin-off of All in the Family - these programs never found an audience, and America seemed to have moved past its need for Lear's hard-hitting formats. 


\section{Conclusion \& Echoes Today}

There were thus three distinct phases to the dominant socialawareness sitcoms of the 1970's, with the second phase, under the reign of King Lear and Queen Mary, most effectively and permanently changing America's television landscape and national identity, by rooting out the evil so as to move past it. Through their groundbreaking sitcoms, their numerous spin-offs and lookalikes, and spin-offs of those same spin-offs, the top-ranked programs of the decade formed a dense network that transmitted social awareness and tolerance through the Trojan horse of laughter and forced America to accept its changing identity (see plate 10).

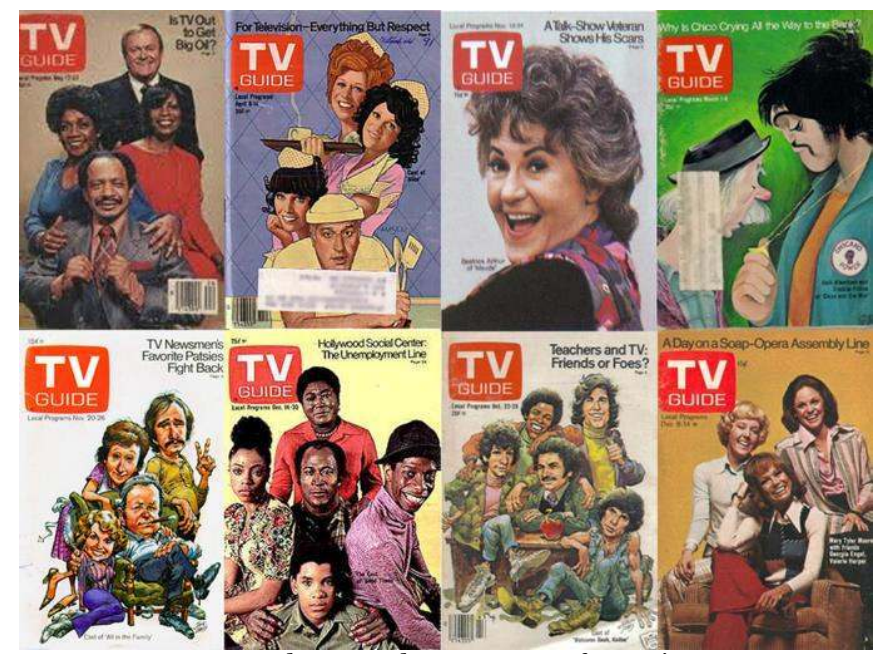

Plate 10: The New Face of America:

Some TV Guide covers from the 1970's

And along with this shift from escapism to pertinence and actuality came the shift from rural to urban landscapes and demographics that Silverman had first initiated at CBS, with most of the top shows in the 1970's, on all three networks, taking place in ghettos or working-class neighborhoods in or around New York, Chicago or Los Angeles (even if, with the live-studio-audience format that was a hallmark of Lear sitcoms, actual location shots of those cities were limited to the opening themes and closing credits). In terms of story-telling, with these programs dealing with social and family problems that were not meant to be resolved in one episode, shows like All in the Family and The Mary Tyler Moore Show were also the first to develop story-lines that continued throughout the season, or from 
season to season, though it was still a far cry from the well-wrought continuous plots of many of today's programs.

One might indeed say that these programs of the 1970's broke so many glass ceilings that we have yet to sweep up all of the broken glass, and that they opened the path for the more readily accepted diversity we find in today's sitcoms and dramatic series. Echoes of these same breakthrough programs are all around us today, particularly on current American television programs, as these characters of the 1970's have become archetypes and common references in American popular culture. Thus, "George Jefferson" and its theme song "Movin' On Up" are common television references to a minority member who goes from rags to riches, as illustrated, for example, in Breaking Bad (AMC, 2008-2013), when Walt's brother-inlaw Hank, a DEA agent, compares a street-dealer turned kingpin to George Jefferson (01.04), or when Darryl on The Office (NBC, 20062013) sings the theme song when he gets promoted (06.18), or when wheelchair-ridden Artie on Glee (Fox, 2009-present) tells his classmates to call him George Jefferson, because his modest showchoir had just won Nationals (03.22). Similarly, in an episode of How I Met Your Mother (CBS, 2009-present), Barney's questionnaire to see if Canadian-born Robin qualifies for American citizenship includes a question on George Jefferson (05.05), demonstrating how much the character is a part of American identity (see plate 11).
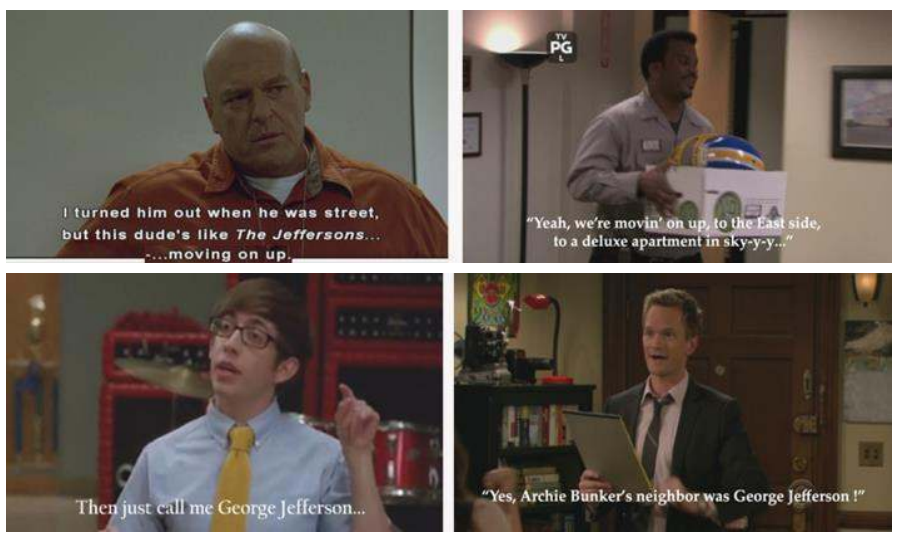

Plate 11: Echoes in Today's Series I:

References made in Breaking Bad (01.04), The Office (06.18), Glee (03.22) and How I Met Your Mother (05.05)

As for the name "Fred Sanford", it can refer to someone living in junkyard-like squalor [as in episode 11 of season 6 of Gilmore Girls (WB/CB, 2000-2007)], being sloppy (as when Chandler discovers that Monica is a 'secret slob' on Friends [(NBC, 1994-2004), 08.14], being a 
verbally abusive father (as when Jack pretends to be Tracy's father during a therapy session on 30 Rock [(NBC, 2006-2013), 02.04], or simply someone who would go as far as faking a heart attack to get attention [as little Billy does on Freaks and Geeks (NBC, 1999-2000), 01.12] (see plate 12).
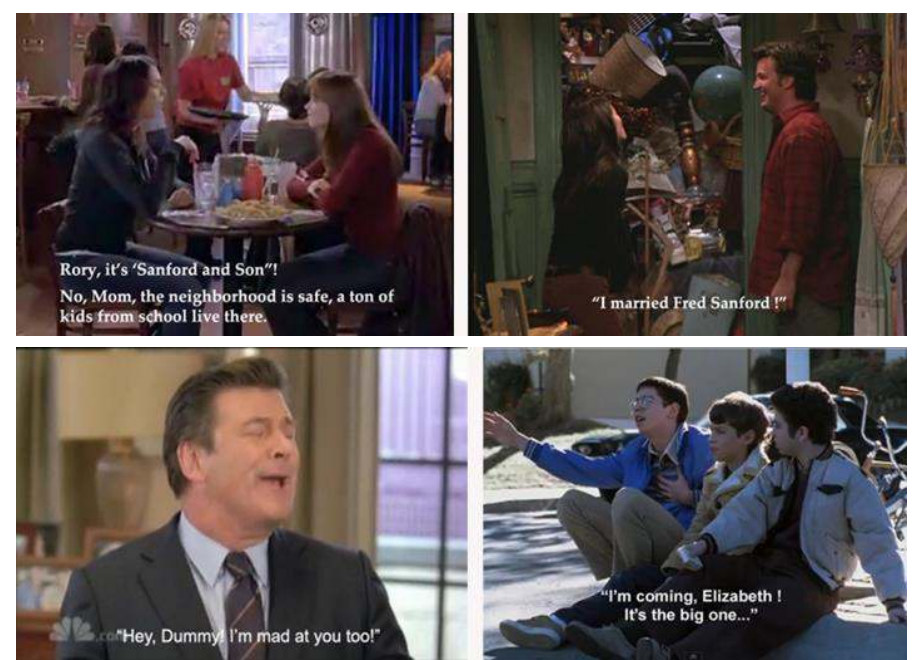

Plate 12: Echoes in Today's Series II:

References made in Gilmore Girls (06.11), Friends (08.14), 30 Rock (02.04) and Freaks \& Geeks (01.12)

Similarly, Mary Richards/Mary Tyler Moore will forever be the archetype of a strong, independent, self-sufficient woman, which is why she is the object of Herc's wild sex fantasy in episode 12 of season 3 of The Wire (HBO, 2002-2008) - though his partner Ellis insists that he could not even get sexual favors from Weezie Jefferson. It is also why, in episode 7 of the last season of Queer as Folk (Showtime, 20002005), Emmet throws his hat in the air when Justin declares that he is going to "make it on [his] own," a wink at Mary's famous hat-toss during the opening credits of her show. Along the same lines, a "Maude" will always be an indomitable feminist, which is why C.J. quotes the theme song when confronted by such a feisty politician in episode 14 of season 6 of The West Wing (NBC, 1999-2006), and calling someone "Kotter", as Jesse does when he first meets Walt in the pilot of Breaking Bad, refers to a well-meaning, liberal teacher trying to help out underprivileged kids (see plate 13). 

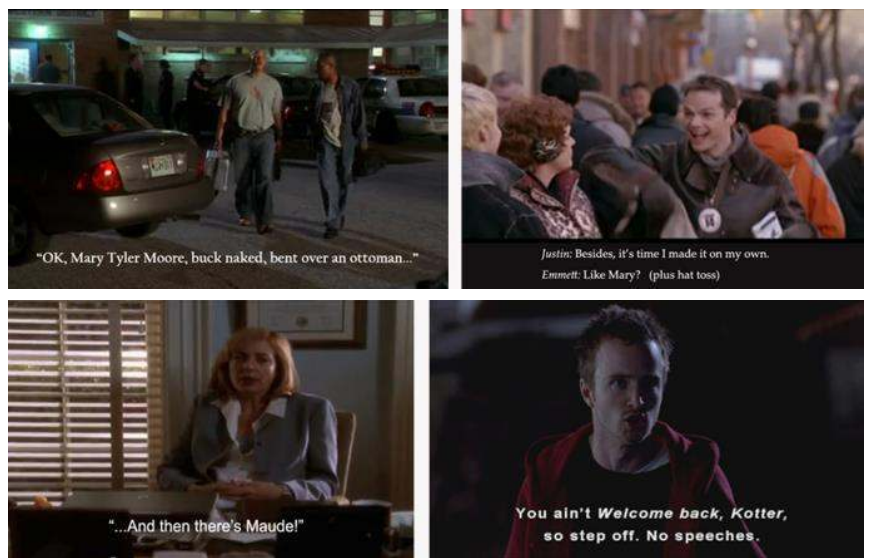

Plate 13: Echoes in Today's Series III:

References made in The Wire (03.02), Queer as Folk (05.07), The West Wing (06.14) and Breaking Bad (01.01)

Even comparatively minor characters from these 1970's sitcoms have become part of the public consciousness, which is why, in the first season of House, M.D. (Fox, 2004-2012), Dr. Foreman confesses that his high school nickname was "Rerun" (01.16), and why on Lost (ABC, 2004-2010), Sawyer calls Hurley "Rerun" when he catches him secretly eating chocolate (02.14), both in reference to the obese but jovial black teen on What's Happening! Similarly, a "Tom and Helen Willis" (a reference to George Jefferson's neighbors and eventual in-laws on The Jeffersons) will forever denote an interracial couple, as it does in an episode (08.07) of Will and Grace (NBC, 1998-2006), which features a gay interracial couple as recurring secondary characters. Finally, calling someone a "Ted Baxter" (the role played by Ted Knight on The Mary Tyler Moore Show) will always refer to a brainless journalist, as it does in another quip by C.J. on The West Wing (02.21) (see plate 14). 

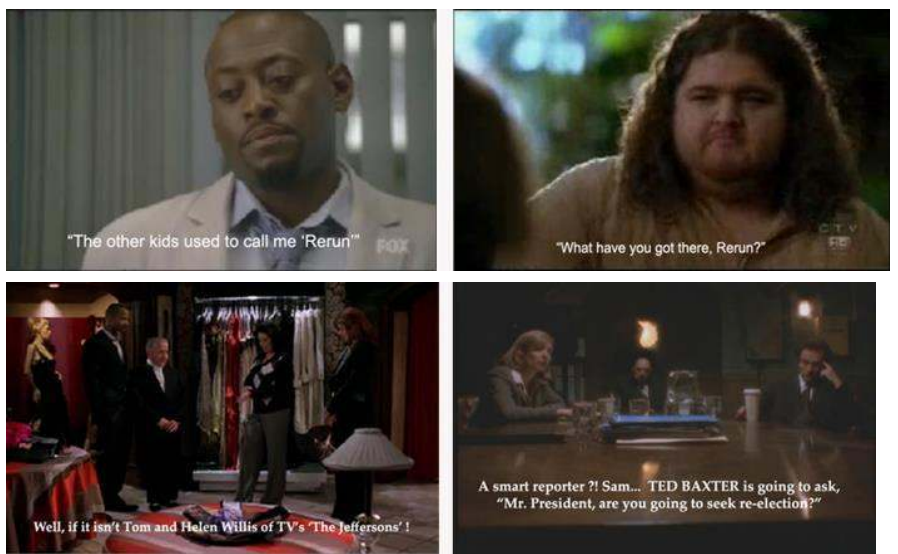

Plate 14: Echoes in Today's Series IV:

References made in House, M.D. (01.16), Lost (02.14), Will and Grace (08.07) and The West Wing (02.21)

Of course, the biggest archetype of them all is Archie Bunker for a loud-mouthed, uneducated, reactionary bigot - which is why the popular animated sitcom Family Guy (Fox, 1999-present) is an irreverent, post-modern parody of All in the Family, right down to the nostalgic theme-song with Peter and Lois at the piano and the black neighbor (Cleveland) who moves away to have his own (albeit animated) ethnicom just like George Jefferson did, and why outspoken conservative radio and television commentators Rush Limbaugh and Glenn Beck are constantly being called today's “Archie Bunkers”. All of this clearly goes to show, if we were not convinced already, that today's television world was truly built upon the breakthrough sitcoms of the 1970's and not simply after them.

\section{Bibliography}

Aronstein A.J., "All in the Family and the First Gay Sitcom Character," Splitsider (May 30, 2012), http://splitsider.com/2012/05/all-in-thefamily-and-the-first-gay-sitcom-character/

Bloom Ken and Vlastnik Frank, Sitcoms, New York, Black Dog \& Leventhal, 2007.

Dominick Joseph R. and GreEnBERG Bradley S., "Three Seasons of Blacks on Television," Journal of Advertising Research, No. 10, 1970, p. 21-27. 
DUCRAY Amandine, Les Sitcoms ethniques à la télévision britannique de 1972 à nos jours : jusqu'à ce que l'humour nous répare, Paris, l'Harmattan, coll. Racisme et Eugénisme, 2009.

DUCRAY Amandine, "Take Me Back to Dear Old Blighty? Déplacements, hybridation et oscillation identitaires dans les séries humoristiques à contenu ethnique à la télévision outre-Manche (19722011)," TV/Series, vol. 2, Nov. 2012 :

http://www.univ-lehavre.fr/ulh services/Numero-2-Issue-2novembre-2012.html

Edgerton Gary R., The Columbia History of American Television, New York, Columbia University Press, 2007.

Fulsom Don, Nixon's Darkest Secrets: The Inside Story of America's Most Troubled President, New York, Thomas Dunnee Books, 2012.

Намамото Darrell Y., Nervous Laughter: Television Situation Comedy and Liberal Democratic Ideology, New York, Praeger Publishers, 1989.

SHAYON Robert Lewis, "Changes," Saturday Review No. 53, April 1970, p. 46.

Tredy Dennis, “Those Were the Days...': All in the Family and the 'Primetiming' of U.S. Diversity and Counterculture," Expressions artistiques et politiques de la contre-culture : La Contestation en images, 1955-1975, E.O.L.L.E. Vol. II, No. 4, Dec. 2012: http://www.univ-lehavre.fr/ulh_services/NUMERO-4.html

\section{The author}

Dennis Tredy is an associate professor of American Literature at the Université de Paris III-Sorbonne Nouvelle. He is co-founder of the ESJS (European Society of Jamesian Studies) and is the main volume editor of two recent books on Henry James: Henry James and the Poetics of Duplicity (2013) and Henry James's Europe: Heritage and Transfer (2011). In addition to his publications on James and on other American novelists (including Steinbeck, Nabokov and Capote), Dennis Tredy has published studies of film adaptations of the works of Henry James, as well as a recently published study of the film adaptations of the stories of Edgar Allan Poe ["From The House of Usher to The Louse of Usher: Expansion Techniques in Film Adaptations of the Works of Edgar Allan Poe in the 1960's and Today," Interfaces (Expanding Adaptations), n $\left.{ }^{\circ} 34,2013\right]$. His recent work on TV series has centered on the representation of American culture, diversity and counter-culture in the 1960's and 1970's. 